\title{
Opinion of Teachers and Students about Futurology of Higher Education in Pakistan
}

\author{
Saima Rasul, Qadir Bukhsh, Muzamilla Akram \\ Department of Educational Training The Islamia University of Bahawalpur, Pakistan
}

\begin{abstract}
Higher education has been witnessing major transformations and facing enormous challenges worldwide in recent years. The role of higher education in today's world is immense, complex, and vital. A wide range of challenges and possibilities are emerging, with political, economic and social implications. This study aims to explore the perception of students and teachers regarding future perspectives of higher education in Pakistan. Questionnaire was used as research tool. Three public sector universities were included as population. The questionnaire was administered to 298 students and 94 teachers from Bahauddin Zakariya University, Multan, The Islamia University, Bahawalpur and The University of Punjab, Lahore. Mean score was calculated for overall level of agreement / disagreement for each statement. For mean score norm was 3.00. However level of agreement was different for each statement. Mcomb is also calculated of students and teachers. Genderwise, Institution-wise and faculty-wise analyses of students and teachers were also made for the comparison of level of agreement by using ChiSquare. The findings for each statement were made. On the basis of findings, the conclusions were drawn. It was found that (i)The respondents viewed that there might be emphasis on research in higher education in future and for this purpose more qualified faculty might be needed.(ii)There might be more access to higher education in Pakistan.(iii)Inter-university linkage might be essential to enrich the academic environment of universities.(iv)Quality of higher education might be brought it to international standard. On the basis of findings of study, following recommendations are made for future of higher education in Pakistan.(1)There should be more emphasis on research in higher education in future. For this purpose, special incentives for research work should be offered for the students and teachers of higher education level. (2) There should be facilities to have more access to higher education.(3)Inter university linkage and university industry linkage should be

developed for better academic environment of university. Industry linkage should be developed for better academic environment of universities and better utility of higher education.(4)Higher education institutions should review the courses annually keeping in view the strengths and weaknesses in the courses

\section{Introduction}

Higher education system of any country directly or indirectly reflects the growth potential, the history, the culture and ethos of a country. In fact an effective higher education system together with its research potential gives an indication of how a country is developing [7]. The 21st century is the age of knowledge-based economy, and the centre stage of change. Higher education has not escaped the impact and is in the process of change, thereby challenging the traditional system of education [1]. Higher education has always played a lead role in the development of a country, and because of the continued influence, the universities of tomorrows will also have the impart education to students of higher standards befitting the 21st century as described by Billing [3] "Higher education is changed with responsibility to transmit the cultural heritage, enriched to push back the frontiers of knowledge to draw out the latent of youth and to be part of the answer to domestic and international problems rather than part of those problems." As Barr [2] described: "Higher education is today recognized as capital investment and is of paramount important for economic and development of the country. Institutions of higher education the main responsibility for equipping individual for advanced knowledge and skills required positions of responsibility in government business and other profession.”

In the time of rapid international, political and economical changes, the universities in Pakistan and developing countries are being transformed. Public expectations about access to higher education government concern about role that universities can play in innovative and economic development [4].
\end{abstract}


Higher Education Commission is struggling hard for the advancement of higher education in Pakistan. A lot of resources are being spent for the attainment of its objectives. Admittedly, Higher Education Commission has been regarding hectic efforts since its inception, but only 2 to $3 \%$ population of Pakistan has been able to avail the benefits and fruits of higher education higher education which is the key to prosperity and development of country as indicated by the Draft Education Policy [5] "The Higher Education System in Pakistan does not performs well. Its relatively tiny size-only $3.7 \%$ of the 18 to 23 age cohort participates in higher education." Higher Education promotes the culture of research as much population will be highly educated in the country there will be enriched culture of research, knowledge-friendship and intellectualism in the country. In this context Mugal [7] comets as "Pakistani universities are confronted with new level of national and international competition as well as new government policies.”

Higher education plays a central role in the development of both human beings and modern societies as it enhances social, cultural and economic development. In other words, higher education is important for the overall development of the country [6]. As Pakistan is a developing country the importance of higher education, therefore, becomes even greater. Developed countries already panned the futurology of higher education to attain the certain objectives of social reconstruction. Higher education enhances the moral commitment to the society as presented by World Bank, 2000 [8]."'Developed countries already planned for future perspectives of higher education. In the present time, no country can assure itself a degree of progress without training and research on the higher level, compatible with the needs and expectations of society. The new touchstones of quality of a higher education are not only its human resource development, but also its moral commitment to society for desirable social change or progress through modernization, even strategic factorization.”

So, it is very important that we have to prepare ourselves for future needs, demands and challenges of higher education. As Combs quoted Lucas "Preparation for the future has been a primary function of education." Higher education is today, the paramount need of developing countries like Pakistan to cope with the demands of present time. Planning should be made about what may be expected future of higher education.

\section{Objectives of the Study}

Following were the major objectives of the study:

1. To find out the responses of students about future perspective of higher education in Pakistan
2. To find out the responses of teachers about future perspectives of higher education in Pakistan

3. To explore the needs, demands and importance of higher education

4. To recommend for future prospects and improvement for higher education most suitable for the society in Pakistan.

\section{Method and Procedure}

The study was descriptive research in nature. A five point rating scale questionnaire was developed to collect the data. The intended target population was all the teachers and students (male and female of science and social science faculties) of Bahauddin Zakariya University, Multan, The Islamia University, Bahawalpur and The University of Punjab, Lahore. Out of the whole population, ninety four teachers and two hundred ninety eight students were selected through simple random sampling technique.

\section{Analysis of Data}

The data was analyzed by SUM, MEAN, percentage with the help of Microsoft excel. ChiSquare was also calculated with the formula ( $\left(X^{2}\right)=\Sigma\left[\frac{(f o-f e)^{2}}{f e}\right]$ ) Where fo = observed frequencies and fe = expected frequencies.

The overall level of agreement or disagreement and made the following comparisons:

I-Gender-wise Analysis

II-Institution-wise Analysis

III-Faculty-wise Analysis

Scale values assigned to each of the five responses was as:

Scale Value

Level of Agreement

$\begin{array}{ll}\text { SA } & 5 \\ \text { A } & 4 \\ \text { UNC } & 3 \\ \text { DA } & 2 \\ \text { SDA } & 1\end{array}$

To calculate the mean score, following formula was used.

Mean

$\underline{(\text { FSAx5+Fax4+FUNCx3+FDAx2+FSDAx1) }}$

$\mathrm{N}$

Where

FSA $=$ Frequency of strongly agreed

$\mathrm{FA}=$ Frequency of agreed

FUNC $=$ Frequency of uncertain

FDA $=$ Frequency of disagreed

FSDA $=$ Frequency of strongly disagreed 
In order to determine the empirical reaction of the students on each item, the mean score on all twentyfive items was calculated in Table 1:

Table 1. The Mean Score

\begin{tabular}{|c|c|c|}
\hline S\# & Statements & $\begin{array}{c}\text { Means } \\
\text { Score }\end{array}$ \\
\hline 1 & $\begin{array}{c}\text { Similarities in questions in } \\
\text { question paper in examination } \\
\text { affect on students'performance }\end{array}$ & 2.74 \\
\hline 2 & $\begin{array}{l}\text { More qualified faculty will be } \\
\text { needed }\end{array}$ & 3.67 \\
\hline 3 & $\begin{array}{l}\text { The traditional teaching methods } \\
\text { will not work in higher education } \\
\text { in future }\end{array}$ & 1.96 \\
\hline 4 & $\begin{array}{l}\text { Higher education education will } \\
\text { be more relevant to the economy } \\
\text { of the country }\end{array}$ & 2.75 \\
\hline 5 & $\begin{array}{c}\text { There will be more access to } \\
\text { higher education }\end{array}$ & 3.32 \\
\hline 6 & $\begin{array}{l}\text { Inter-university linkage will be } \\
\text { essential to enrich the academic } \\
\text { environment of universities }\end{array}$ & 3.20 \\
\hline 7 & $\begin{array}{c}\text { Higher education will enable an } \\
\text { individual to meet the challenges } \\
\text { of life }\end{array}$ & 3.22 \\
\hline 8 & $\begin{array}{c}\text { Quality of higher education will } \\
\text { bring it to the international } \\
\text { standard }\end{array}$ & 3.66 \\
\hline 9 & $\begin{array}{c}\text { No drastic changes will emerge in } \\
\text { higher education }\end{array}$ & 3.24 \\
\hline 10 & $\begin{array}{l}\text { More higher education will cause } \\
\text { more un-employment }\end{array}$ & 4.05 \\
\hline 13 & $\begin{array}{l}\text { There will be more emphasis on } \\
\text { economically useful discipline }\end{array}$ & 3.09 \\
\hline 14 & $\begin{array}{l}\text { More funding will be needed for } \\
\text { quality higher education }\end{array}$ & 4.16 \\
\hline 15 & $\begin{array}{l}\text { There will be an effective } \\
\text { monitoring system in higher } \\
\text { education }\end{array}$ & 2.52 \\
\hline 16 & $\begin{array}{l}\text { Monitoring system will ensure } \\
\text { quality higher education }\end{array}$ & 3.13 \\
\hline 17 & $\begin{array}{l}\text { Higher education will be helpful } \\
\text { in socio-economic development } \\
\text { of Pakistan }\end{array}$ & 3.80 \\
\hline 18 & $\begin{array}{c}\text { Higher education will become } \\
\text { privilege not a right }\end{array}$ & 3.82 \\
\hline 19 & $\begin{array}{l}\text { There will more use of } \\
\text { technology for responding to the } \\
\text { advancement in knowledge }\end{array}$ & 3.30 \\
\hline 20 & $\begin{array}{l}\text { Higher education will help to } \\
\text { develop scientific and rational } \\
\text { approach towards life among its } \\
\text { recipients }\end{array}$ & 4.06 \\
\hline 21 & $\begin{array}{l}\text { Only market-oriented discipline } \\
\text { will become important }\end{array}$ & 2.72 \\
\hline 22 & $\begin{array}{l}\text { Private sector will become more } \\
\text { effective than the public sector }\end{array}$ & 2.79 \\
\hline 23 & $\begin{array}{l}\text { Higher education will develop } \\
\text { international understanding for } \\
\text { better and peaceful Pakistan }\end{array}$ & 3.15 \\
\hline 24 & $\begin{array}{l}\text { Information explosion will bring } \\
\text { frequent changes in curricula of } \\
\text { all discipline }\end{array}$ & 3.04 \\
\hline
\end{tabular}

\begin{tabular}{|c|c|c|}
\hline 25 & $\begin{array}{c}\text { Only skill-oriented education will } \\
\text { be valid in future }\end{array}$ & 2.41 \\
\hline 26 & $\begin{array}{c}\text { Technology will take over the } \\
\text { role of teacher }\end{array}$ & 2.83 \\
\hline 27 & $\begin{array}{c}\text { Higher education will develop } \\
\text { better leadership qualities among } \\
\text { its recipients }\end{array}$ & 3.41 \\
\hline 28 & $\begin{array}{c}\text { Social sciences and Humanities } \\
\text { will become redundant in higher } \\
\text { education }\end{array}$ & 2.49 \\
\hline 29 & $\begin{array}{c}\text { Private sector will play important } \\
\text { role in higher education as } \\
\text { compare public sector }\end{array}$ & 2.97 \\
\hline 30 & $\begin{array}{c}\text { Economically less important } \\
\text { discipline will eliminate }\end{array}$ & 3.16 \\
\hline \multicolumn{2}{|c|}{} \\
\hline
\end{tabular}

Above table shows mean score of teachers and students for each statement. According to this table teachers' maximum mean score on statement no 12 was 3.46 and minimum mean score on statement no 26 was 1.96 . Similarly students' maximum mean score on statement no 14 was 4.16 and minimum mean score on statement no 3 was 1.96. The researcher also calculated Mcomb of teachers and students respectively $2.94,3.14$ which shows that students 'perception regarding future perspectives of higher education is greater than teachers' perception of higher education in Pakistan.

\section{Comparison between Levels of Agreement/Disagreement}

The researcher analyzed the overall level of agreement or disagreement and made the following comparison:

\subsection{Students -Wise Analysis}

\section{- Gender - wise analysis}

The researcher made the comparison between level of agreement/disagreement of male and female students. For this purpose, the average scores for all the thirty items and for all the students included in the study with respect to gender of the respondents were calculated. These were the observed frequencies. The calculated value for chi square was 4.06 and the table value for Chi-Square is 9.488 and 13.277 at .05 and .01 level of confidence respectively, and 4 degree of freedom. As the calculated value of Chi-Square is less than the table values at .05 and .01 level of confidence, therefore there is no significant difference in the level of agreement/disagreement about the items between the male and female students s' perception about future of higher education in Pakistan. 


\section{- $\quad$ Faculty -wise analysis}

The researcher made the comparison between levels of agreement/disagreement with respect to faculties of the respondents from the Bahauddin Zakariya University, Multan, The Islamia University, Bahawalpur, The University of Punjab, and Lahore. For this purpose average Score for all the thirty items and for all the students included in the study with respect to the faculties of the respondents were calculated and tabulated in the table 3: There were the observed frequencies. After calculating expected frequencies in the above table, the researcher calculated the value of Chi-square by using the formula as described above. The calculated value for Chi- Square was 1.43. The table values are 9.488 and 13.277 at 05 and .01 levels of confidence respectively, and at 4 degree of freedom. As the calculated value of chi-square is less than table value and 0.5 and .01 level of confidence, therefore there is no significant difference in the level of agreement disagreement about the items between the social science and Science faculties' students perception about future of higher education in Pakistan.

\section{- Institution - wise analysis}

The researcher also made the comparison between level of agreement disagreement of the students from Bahauddin Zakariya University, Multan, The Islamia University, Bahawalpur and The University of Punjab, Lahore .For this purpose, the average scores for all thirty items and for all the respondents included in the study with respect to institution of the respondents were calculated. After calculated expected frequencies in the above table, the researcher calculated the value of chi-square by using the formula as described above. The calculated value for chi-Square was 18.51.The table value for chi-square are 9.488 and13.277 at.05 and .01 level of confidence respectively and at 4 degree of freedom. As the calculated value of chi-square is greater than table values at .05 and 0.1 level of confidence, therefore there is significant difference in the level of agreement /disagreement about the items in the modle, between the respondents from Bahauddin Zakariya University, Multan, Islamia University, Bahawalpur and The University of Punjab, Lahore.

\subsection{Teachers- Wise Analysis}

\section{- Gender -wise analysis}

The researcher made the comparison between level of agreement and disagreement of make and fenced teachers. For this purpose, the average scores for all the thirty items and for all the respondents included in the study with respect to gender of the respondents were calculated and tabulated in the table no 5. These were observed frequencies. After calculating expected frequencies in the above table the researcher calculated the value of Chi-. Square by using the above mentioned formula. The calculated value for Chi- Square was 0.47 .The table values are 9.4888 and 13.277 at 0.5 and .01 level of confidence respectively, and at 4 degree of freedom. As the calculated value of Chi -square is less than the table value and .05and .01 level of confidence therefore there is no Significant difference in the level of agreement /disagreement about the items between the male and female teachers perception about future of higher education about future of higher education in Pakistan.

\section{- $\quad$ Faculty -wise analysis}

The researcher made the comparison between levels of agreement and disagreement with respect to the faculties of respondents from Bahauddin Zakariya University, Multan, The Islamia University, Bahawalpur and The University of Punjab, Lahore. For this Purpose average Score for all the thirty items and for all the teachers included in the study with respect to the faculties of the respondents were calculated and tabulated in the table .07. These were the observed frequencies.

After calculating expected frequencies in the above table the researcher calculated the value of $\mathrm{Ch}$ Square by using the formula as described above. The calculated value for Ch-Square was 5.32. The table values are 9.4888 and 13.2 at 05 and .01 levels of confidence respectively and at 4 degree of freedom. As the calculated value of Chi- Square is less than table value, there for there is no significant difference in the level of agreement / disagreement about the items between science and social science teacher's perception about future perspectives of higher education in Pakistan

\subsection{Students-Wise Analysis}

The researcher analyzed the overall level of agreement and disagreement of teachers and made the following comparison.

\section{Conclusions}

On the basis of above mentioned findings, the following conclusions were drawn:

- The respondents viewed that there might be emphasis on research in higher education in future and for this purpose more qualified faculty might be needed.

- There might be more access to higher education in Pakistan. 
- Inter-university linkage might be essential to enrich the academic environment of universities.

- Quality of higher education might be brought it to international standard.

- University-industry linkage might be essential for better utility of higher education in future.

- There might be more emphasis on economically useful and new disciplines.

- Higher education might be developed international understanding for better and peaceful Pakistan.

- Information explosion might be frequent changes in curricula of all disciplines.

- Higher education might develop better leadership qualities among its recipients.

- The traditional teaching methods may work in higher education in future.

- Private sector might not become more effective than public sector.

- Only skill-oriented education might not valid in future.

- Technology might not take over the role of teacher.

- Social science and Humanities might not redundant in higher education.

\section{Recommendations}

Based on the research study, following recommendations are made for future of higher education in Pakistan:

- There should be more emphasis on research in higher education in future. For this purpose, special incentives for research work should be offered for the students and teachers of higher education level.

- More qualified faculty should be appointed, with certain incentives.

- Higher education should be relevant to the economy of the country.

- There should be facilities to have more access to higher education.

- Inter university linkage and university industry linkage should be developed for better academic environment of university. Industry linkage should be developed for better academic environment of universities and better utility of higher education.

- Higher education institutions should review annually every faculty's different strengths and weaknesses; the courses should be judged and accordingly suitable changes, if necessary, should be made in the courses.

\section{References}

[1] Bharat, B. Dhar, (2008), Higher education system, New Delhi: A.P.H publishing corporation.

[2] Barr, N. A., (2005), Financing Higher Education, Boston: Finance and Development of Boston University.

[3] Billing, D., (2004), Challenges of Higher Education, Netherlands: Kuwer Academic publishers, http://www.isikun,edu.tr/vardar/david/pdf. (Access date: August 22, 2010).

[4] Chalam, K. S., (2005), Challeges of Higher Education, New Delhi, Anmol publication PVT.LTD.

[5] Govt. of Pakistan, (2009) Draft Education Policy, Ministry of Education, Pakistan: Islamabad.

[6] Harvey, L., (2003), Higher Education: Current Situation and Issues, Wellington: http://www.qualityresearchinternaitonal.com/ publications/wellington.pdf. (Access date: July 3, 2005).

[7] Mugal, W.A., (1999), Issues in Higher Education: Problems and prospect of Pakistani universities, Pakistan:University of Sindh Jamshoro.

[8] World Bank, (2000), Development in Practise, Higher Education, Washington. 